\title{
Russian Art and Russian Studies at Dartmouth: Case of Ralph Sylvester Bartlett
}

\author{
Robert H. Davis, Jr.
}

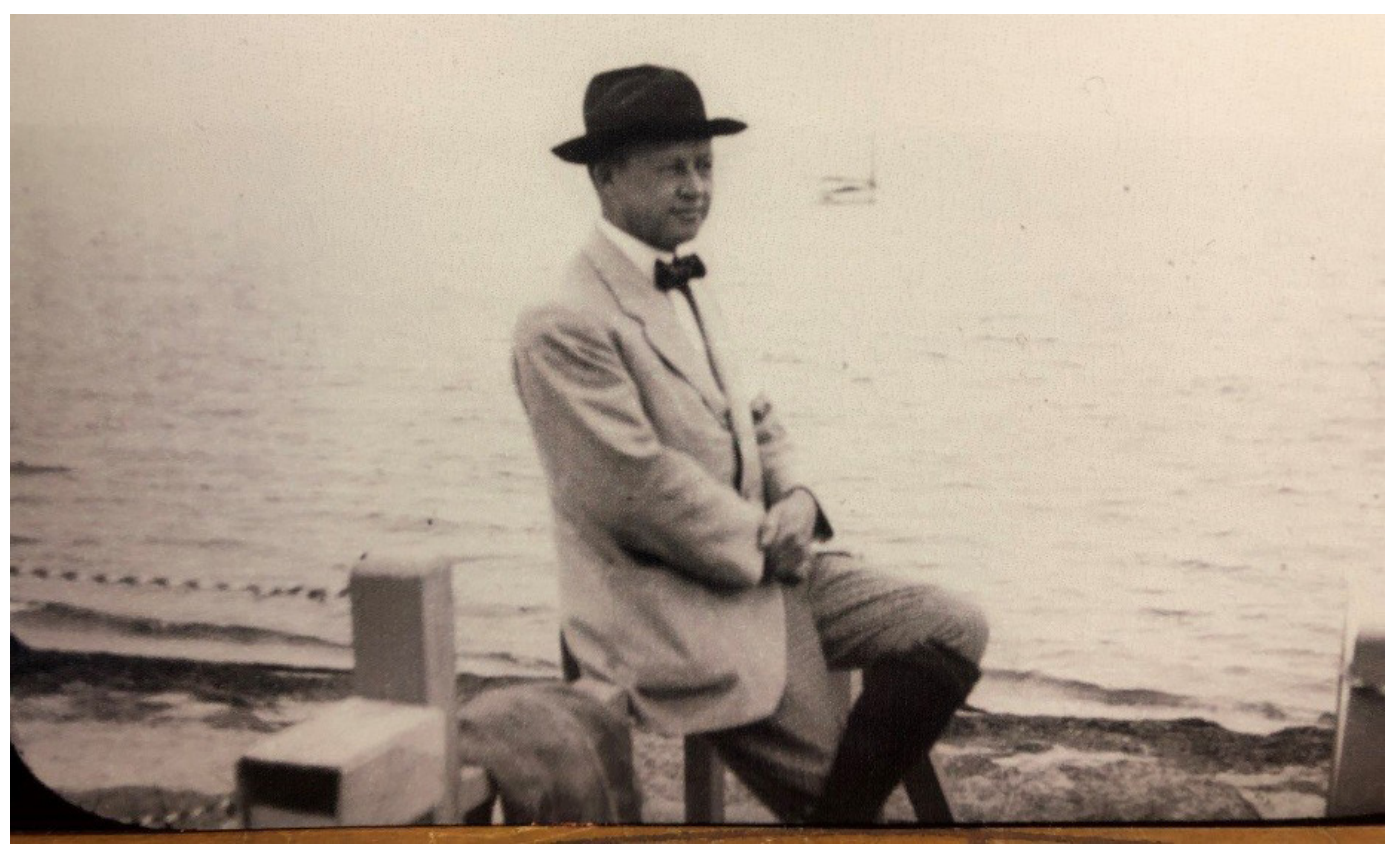

Ralph Bartlett, on Tuckernuck Island, Nantucket. Courtesy of Peter Narbonne, Eliot, Maine.

In archival files at the Hood Museum at Dartmouth College, there is a marvelous photo of a jowly gentleman, garbed in a Georgian chokha, clutching a traditional dagger. Although the photo was snapped in Soviet Georgia, in Ordzhonikidze, in 1933, the face that stared back at me was that of the archetypical northern New Englander. With my own roots deep in the rocky soil of three New England states, it was a type I knew very well. ${ }^{1}$ This was my first "encounter" with Ralph Sylvester Bartlett, Esq. (1868-1960), Dartmouth College Class of 1889. ${ }^{2}$

1 Perhaps more familiar than I originally thought: both my first paternal ancestor in the New World, John Davis (d. 1675), and Ralph's forebear Richard Bartlett (d. 1647) settled in Newbury, Massachusetts, in 1635.

2 In the preparation of this article, the following individuals have provided invaluable assistance: Peter Narbonne of Eliot, Maine generously provided scans from Ralph's huge collection of lantern slides. Eric J. Esau of Dartmouth's Rauner Special Collections Library located images of Ralph's reunion classes, copies of his many Class of 1889 reports, and internal Dartmouth memoranda pertaining to Bartlett's gifts to the College. Joan Waldron of Portsmouth, New Hampshire was instrumental in contacting and interviewing Ralph 


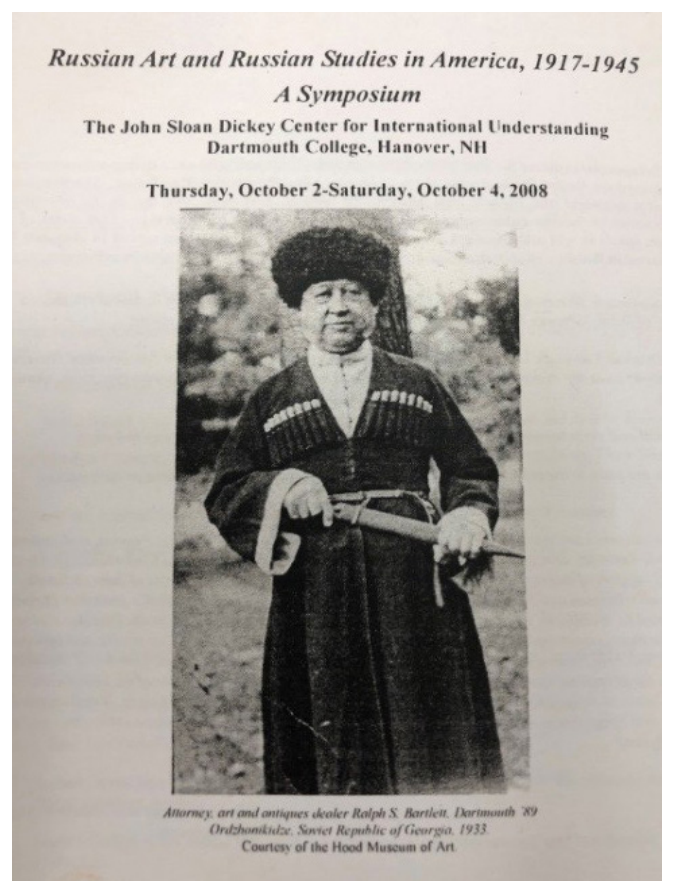

Cover of the 2008 Symposium Program.
Yet while the face was familiar, the man was not. Bartlett looked for all the world like a prosperous farmer or smalltown lawyer, and yet during his lifetime he had amassed one of the nation's largest collections of Russian objets d'art from the imperial period. In the years immediately preceding his death on September 19, 1960, Bartlett bequeathed this marvelous collection of over three hundred items to his alma mater, asking in return only funeral and burial costshe is interred in Hanover's Pine Knoll Cemetery - and a small annuity during his lifetime.

In 1992, when I first examined the files connected with the Bartlett gift, I was just beginning to explore questions surrounding the migration of books and

art objects from Soviet Russia during the 20s and 30s. ${ }^{3}$ I was taken aback by the diversity and quality of materials Bartlett had assembled, including icons, porcelain, oils, textiles, and items in silver and gold ranging from the $17^{\text {th }}$ through early $20^{\text {th }}$ centuries. ${ }^{4}$ Although some of the objects collected by Bartlett could be considered of marginal aesthetic or historic value, many are indeed spectacular museum pieces. In its entirety, the collection is perfectly suited to the diverse needs of a teaching museum such as the Hood. ${ }^{5}$ An international conference sponsored

Bartlett's cousin, the late Joseph W.P. Frost, and in subsequently locating other visuals of the Bartlett family, from the collection of her late husband (and Dartmouth ' 43 graduate) Jeremy R. Waldron.

As always, my long-time colleague Edward Kasinec deserves great thanks for his role in initiating this investigation.

3 The topic of Soviet-era nationalization and sale of art objects, books and manuscripts is now well-documented. Since the pioneering Russian Art and American Money, 1900-1940 (Cambridge, Ma., 1980) by Robert Williams, a number of studies of this topic have appeared on both sides of the Atlantic, shedding new light on the question of what was sold, how it was sold, and who were the sellers and buyers. For example: Sean McMeekin's History's Greatest Heist: The Looting of Russia by the Bolsheviks (New Haven, 2009); the compendium Treasures into Tractors: The Selling of Russia's Cultural Heritage, 1918-1938 (Washington, DC, 2009); and Selling Russia's treasures: the Soviet trade in nationalized art, 1917-1938 (Paris and New York, 2013).

4 A complete inventory of the Bartlett Collection is available via the Hood Museum's web search feature. http://hoodmuseum.dartmouth.edu/collections/search.html

5 In addition to the items that are currently held by the Hood Museum, there were a handful of others that were subsequently deaccessioned, or sold to other institutionsmost remarkably (and for obvious reasons) a large crystal chandelier purportedly from the Pavlovsk Palace, which at the time of his death Bartlett had on long-term loan to Gore Place, a historic home in Waltham, Massachusetts. 
by the Dickey Center at Dartmouth College in October $2008^{6}$ provided many attendees and the general public their first opportunity to appreciate the substance and diversity of the Bartlett collection, through special exhibitions at the Hood Museum, Baker-Berry Library, and the Rauner Special Collections Library. ${ }^{7}$

Finding such a rich trove on a college campus was unexpected. The Hood Museum archival materials that I examined pertained exclusively to the mechanics of appraising, and accessioning Bartlett's bequest, and provide few details concerning his background, interests, and motivation for assembling the collection. In the years that have followed, some of these blank spots have been filled in with substantive details of Bartlett's life and involvement with "things Russian."

Ralph Sylvester Bartlett was born in 1868 at the family homestead in Eliot, Maine, on the site of a colonial-era blockhouse and $17^{\text {th }}$ century massacre. The son of a well-to-do farmer who also was part owner of ships engaged in foreign trade (and a descendent through his mother of Sir William Pepperell, 1696-1759, the hero of Louisburg during the French and Indian war), Ralph graduated from of Eliot's Berwick Academy in 1885, and from Dartmouth with the Class of 1889. ${ }^{8}$

6 "Russian Art and Russian Studies in America, 1917-1945: A Symposium," The John Sloan Dickey Center for International Understanding Thursday, October 2-Saturday, October 4, 2008. The Symposium was conceived and organized by Edward Kasinec, with the assistance of the present author, when both were still at The New York Public Library. It explored the rich cultural (as well as political and economic) dialogue between Soviet Russia and the United States during the two decades after the Russian Revolution, highlighting the historic role Dartmouth alumni, Curators, and faculty played in fostering an appreciation of foreign cultures broadly, and of Russian culture in particular. Participants addressed the ways in which the decorative and visual arts served to stimulate both an interest in Russia and its culture, and to establish the notion of Russian artistic achievement.

The Dartmouth symposium would not have been possible without the assistance of Ambassador Kenneth Yalowitz, the now retired Director of the Dickey Center, and former Dartmouth Provost Barry Scherr. John De Santis of the Baker-Berry Library did an outstanding job in planning and implementing conference activities.

7 The Kim Gallery of the Hood Museum was the venue for "European Art at Dartmouth: Highlights of the Hood Museum of Art," with a special exhibition of Russian objets from the Ralph S. Bartlett Collection. The exhibit was prepared by the late Anne Odom of the Hillwood Museum in Washington, DC, and T. Barton Thurber of the Hood, presently Director of the Frances Lehman Loeb Arts Center at Vassar College.

Baker Library presented an exhibition of book materials entitled "Bringing Russia to Dartmouth: The Legacy of Ralph Sylvester Bartlett" curated by John C. DeSantis, Dartmouth College Library, while the Rauner Special Collections Library offered "An Imperial Provenance: Four Books from the Romanov Libraries Now at Dartmouth," an exhibit curated by Eric J. Esau, Dartmouth College Library.

8 Helen Goransson of Eliot, Maine, has penned a research-based account of Ralph Bartlett and his family entitled Views from Rosemary Hill (Portsmouth, NH: Jetty House, 


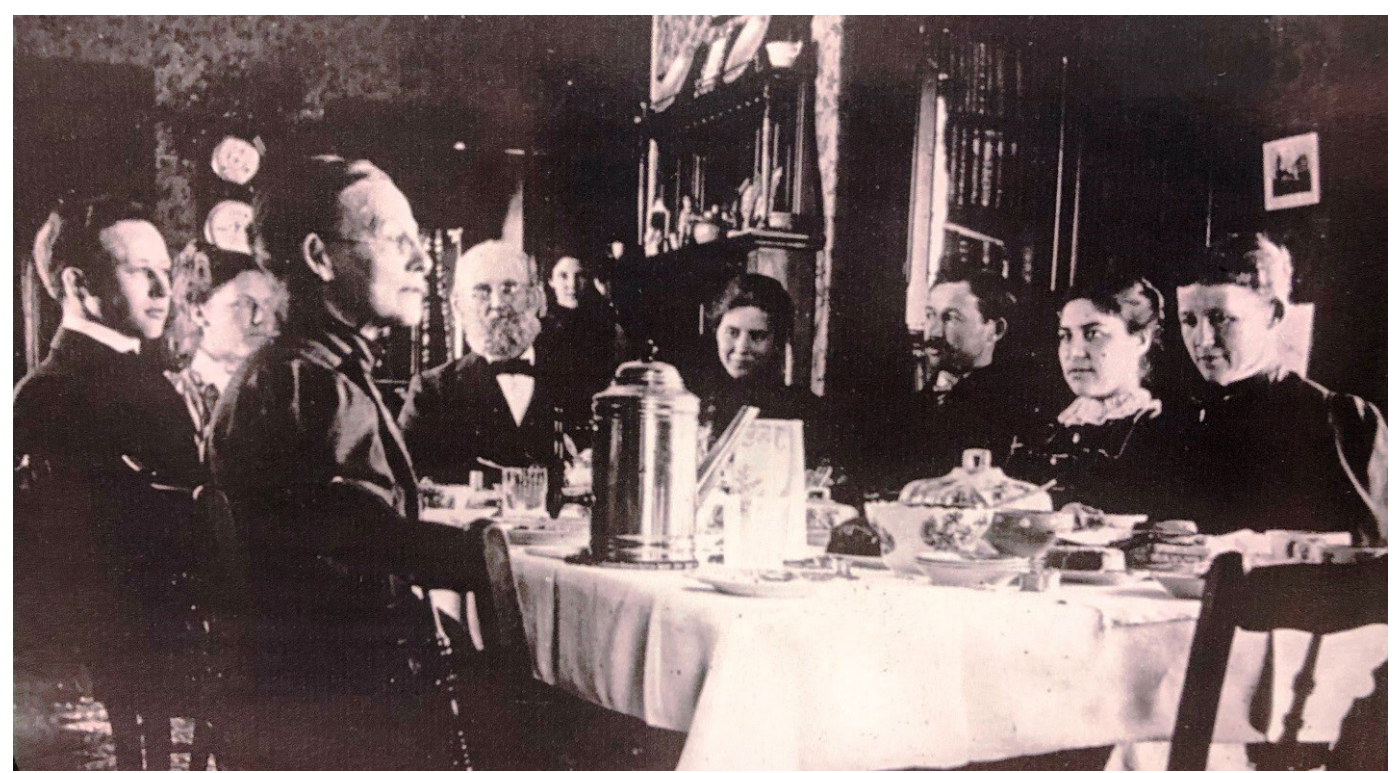

Sunday Brunch at the Bartlett Homestead. Ralph is seated at left center. Courtesy of Peter Narbonne, Eliot, Maine.

He went on to earn a law degree from Boston University in 1892, and formed his own practice with four associates in a suite of offices at the Exchange Building at 53 State Street Boston. By all accounts, Bartlett was good at what he didlargely, but not exclusively, trusts and estates — and he practiced law from 1896 until 1933. ${ }^{9}$ Yet, as some of his jottings to his classmates make clear, in his heart of hearts, he aspired to do things beyond the comfortable life of a Boston lawyer. As he put it in one note, written during his second year of law school

I have been trying to digest some very indigestible portions of real property, bills and notes, etc., and am still "grinding." Yet I still have a good appetite and the best of health, so still have hopes of grinding out and digesting the full course here by a year from June. By that time, I think I shall need a change of diet, but not having as yet decided just what that will be I cannot inform you at this time. ${ }^{10}$

As a dapper bon-vivant in the big city, Ralph resided at the Massasoit Club at 531 Mass. Ave., and threw himself into the social diversions of the University Club

2010). She devotes considerable attention to the Bartlett and related families from their earliest times in North America.

9 Early in his career, Ralph took on the (unsuccessful) defense of one Michael J. Kilroy of East Boston, a coal shoveler, who stood accused of beating his wife to death in a drunken rage. The story was a sensation. "Kilroy's Case Trial begins in Superior Criminal Court," Boston Daily, October 7, 1902, p. 7.

${ }^{10}$ Second Report of the Class of Eighty-Nine, Dartmouth College, June, 1891, p. 22. A brief biographical sketch of young Bartlett appears in Men of Progress: One Thousand Biographical Sketches and Portraits of Leaders in Business and Professional Life in the Commonwealth of Massachusetts (Boston, 1896), pp. 841-42. 
(where he was described as a "genial and favorite member"), and of Company B, First Corps of Cadets of the Massachusetts National Guard. By 1894, when Ralph first joined, the latter organization - founded in 1741 — seemed less interested in drilling than frolicking, principally in the form of stage follies. ${ }^{11}$ Bartlett clearly had a sense of fun.
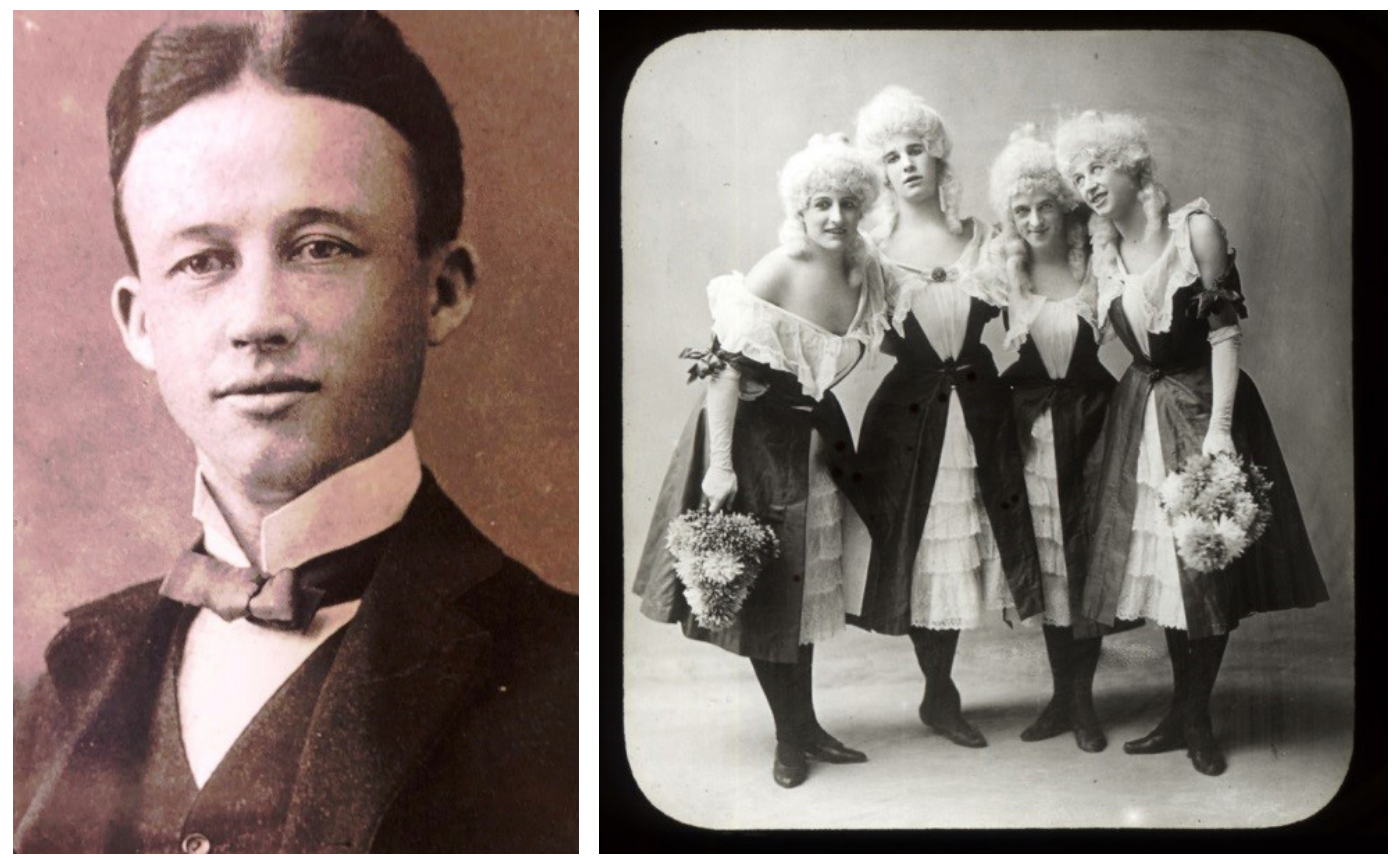

Ralph circa 1890s (left), and (at far right), as a participant in the First Corps' Follies. Courtesy of Peter Narbonne, Eliot, Maine.

Ralph's "change of diet" seems to have been precipitated by his involvement with the widow and daughter of Ole Bull (1810-1880) the famed $19^{\text {th }}$ century Norwegian violinist. Bull traveled extensively in America during the latter half of the $19^{\text {th }}$ century, and in 1870 took as a second wife Sara Thorp (1850-1911), forty years his junior, the daughter of a US Senator and lumber baron from Wisconsin. Sara, Ole, and their young daughter Olea (1871-1911), moved to Cambridge, Mass., renting "Elmwood," the home of the then-Minister to the Court of Spain James Russell Lowell (1819-91). There, Bull and his wife hob-nobbed with local luminaries such as the poets Henry Wadsworth Longfellow (1807-82) and John Greenleaf Whittier (1807-92). ${ }^{12}$ After Bull's death in Lysøen, the widowed Sara became an important figure in the cultural and social life of Boston, organizing the so-called Cambridge Conferences, lectures of leading literati and intellectuals, held at her home on Brattle Street twice yearly in the closing years of the nineteenth century. ${ }^{13}$ In summers, Sara kept a cottage in Eliot, Maine.

In the years preceding her death in 1911 Sara had become-in the opinion of some - not "of sound mind." Sara had developed a deep interest in the teach-

${ }^{12}$ On Bull and his career from the pen of his devoted second wife, see Sara Chapman Thorp Bull's Ole Bull: A Memoir (Boston, 1883), passim.

${ }^{13}$ See her entry "Sara (Thorp) Bull" in the Cambridge Women's Heritage Project Database, 


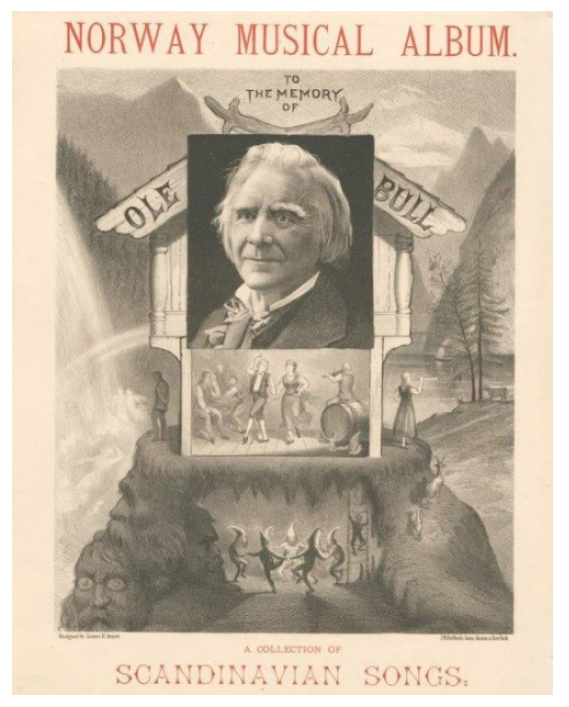

Music Division, The New York Public Library. "To the memory of Ole Bull" The New York Public Library Digital Collections. http://digitalcollections. nypl.org/items/510d47dc-8bde-a3d9e040-e00a18064a9 ings of Swami Vivekananda (1863-1902), the renowned proponent of Vedanta philosophy and Yoga in America and Europe. ${ }^{14}$ She was one of several Americans named as executors of the Swami's will. ${ }^{15}$ She became known to Vivekananda's followers as "Saint Sara," and in a revised will left a sizeable portion of her inheritance to individual members of his sect. ${ }^{16}$ After Sara's death, Ralph took the case of her daughter, Olea Bull Vaughan, challenging the will on the grounds that Sara was under duress, and possibly insane at the time she wrote it, and a parade of witnesses described how Mrs. Bull believed she was regularly consulting the dead. ${ }^{17}$ Ralph ultimately won the case, and

${ }_{14}$ She was hardly alone. Lectures and presentations during Vivekananda's two trips to the United States, in 1893-96, and again in 1899-1900 drew many prominent and admiring attendees, including Harvard's dean of the faculty of theology, Charles Carroll Everett (18291900), and the psychologist (and brother of Henry) William James (1842-1910), among many others. Vivekananda was offered academic chairs at both Harvard and Columbia Universities.

${ }^{15}$ Sara's summer cottage, "Lyselven," bordered the still-extant Green Acre Baha'i School in Eliot, Maine. Today, it serves as the school's library. Green Acre Inn, established by Sarah Farmer in 1894, became a meeting place for ideas from varying philosophies and religions. The Inn drew a fascinating crowd of intellectuals to Eliot during the early years of the twentieth century, ranging from W.E.B. DuBois, to William Dean Howells; from Sara Bull to John Greenleaf Whittier. Farmer's adoption of the Baha'i' faith was precipitated by her meeting Abdul-Baha'i in 1900. On Farmer and Green Acre, see: "Greenacre-onthe-Piscataqua," New York Times, September 19, 1897, p. IW6; and Green Acre on the Piscataqua: A Centennial Celebration (Eliot, Me., 1991), and www.greenacre.org.

${ }^{16}$ See Pravrajika Prabuddhaprana. Saint Sara: The Life of Sara Chapman Bull, the American Mother of Swami Vivekananda (Calcutta, 2002). At the time the will was presented to the court, it was the longest document ever probated in York County, Maine, with later codicils bequeathing substantial sums to Swami Saradananda, Jagadla Chunder Boss of Calcutta, and Margaret E. Noble, also of Calcutta.

${ }^{17}$ See, for example "Will case bares Vedanta Mysteries," Boston Daily Globe, May 28,1911, p. 25 . In addition to outlining the financial stakes and dramatis personae of the case, the article notes some of Mrs. Bull's erratic behavior, such as wiping the furniture in a room with olive oil and ammonia following a visit to her Cambridge home by the feminist educator May Wright Sewall (1844-1920) of the International Congress of Women, to "take off the hypnotism" of what Sara felt were the latter's evil intentions. Elsewhere, it was stated that she feared death via a "killing thought" transferred over the phone lines, administered by an unnamed Lebanon, Maine woman. "Made Ill by Thought Wave, Mrs. Bull Feared Death by Same Means" Boston Daily Globe, May 17, 1911.

Even her fellow Vivekananda executrix, the noted Anglo-Irish social worker and educator, Mrs. Margaret E. Noble (known as Sister Nivedita, 1867-1911) was forced to 
Olea got her sizeable inheritance. ${ }^{18}$ She had no opportunity to enjoy it, however, for even as the judge in the case was pronouncing his decision, emotionally frail, long-sickly Olea died of tuberculosis, leaving Ralph responsible for the legal guardianship of Olea Bull Vaughn's “adoptive” daughter, Sylvea (1907-88) sometimes described as her foster daughter, as the adoption was never legalized. ${ }^{19}$ Throughout the rest of his life, Ralph would be a central participant in all the high-points of her life- he was present at (and filmed) her graduation from Smith (Class of '30), and walked her down the aisle at her wedding in 1932. ${ }^{20}$

In 1911, Ralph travelled to Lysøen, the island home of Ole Bull in Norway, of which he was now, in essence, custodian. It wasn't his first time there, having visited Norway in 1906 when he attended (with Sara and Olea Bull in happier times) the coronation of King Haakon VII (1872-1957).

admit that in her final days, Sara was "...perfectly crazy, out of her mind." (Cited from an article by Edwin J. Park. "Letters from JoJo Are Read: Messages reported to be from Dr. Coulter, long dead," Boston Daily Globe, June 16, 1911. Another press account ("Thought Mrs. Bull Insane. Miss Noble, Important Witness in the Will Case, is in India," New York Times, June 8, 1911, p. 3) states that Ralph read letters at the trial stating that "Miss Noble has expressed her misgivings and fears in relation to Mrs. Bull's mental condition. Miss Noble has described various actions on the part of Mrs. Bull which seem to indicate that she was acting in relation to her daughter under the fear of some malign influence..."

Helen Goransson (Op. cit.) devotes extensive attention to Ralph Bartlett's relationship with the Bull family, particularly during the nasty legal machinations surrounding his challenge to Sara's will.

18 "Thousands for Adopted Child, Will of Mrs. Olea Bull Vaughn [sic] is Filed. Sylvia [sic] Bull Vaughn gets bulk of $\$ 500,000$ Estate. Atty Bartlett and Miss Shapleigh Benefit," Boston Daily Globe, October 3, 1911.

${ }^{19}$ Helen Goransson (Op. cit.) provides evidence that Sylvea was, in fact, the illegitimate child of Ralph and Olea. See pp. 158-60, and pp. 186-87.

Following Olea's death, Bartlett and his cousin, Miss Amelia Shapleigh, were named legal guardians of five year old Sylvea in June of 1912. See "Guardians Appointed," Boston Daily Globe, June 5, 1912, p. 2. Sylvea took Shapleigh as her surname, and in published accounts refers to Ralph and Amelia as her aunt and uncle. Olea's ex-husband, Henry Goodwin Vaughan (1868-1938), was a Harvard-educated lawyer and avid fox hunter and yachtsman from an old Cambridge family. See: "Olea Bull Married," Boston Daily Globe, February 6, 1894, p. 10.

Their marriage in 1894, much reported on at the time, was evidently an unhappy one, and their only daughter, Edwina, died in infancy. See Goransson, Op. cit., pp. 156-58.

20 "Sylvia [sic] Shapleigh Bride," New York Times, June 12, 1932. She was married in West Lebanon Maine by the prominent Unitarian minister, social activist, and founder of the Community Church of New York, John Haynes Holmes (1879-1964). Her first husband, Mortimer B. Smith, died in 1981. They had four children, and divorced sometime before 1959, when she married Nelson G. Curtis. Sylvea is fondly remembered in Norway, for in 1974 - in the presence of the Norwegian royal family — she presented Lysøen and its contents to the Norwegian Society for the Preservation of Ancient Monuments. One Ole Bull item which was not given to Norway was his 1647 Nicolo Amati violin, which ended up in the possession of Sylvea's first husband in 1962, and sold in 1967. 


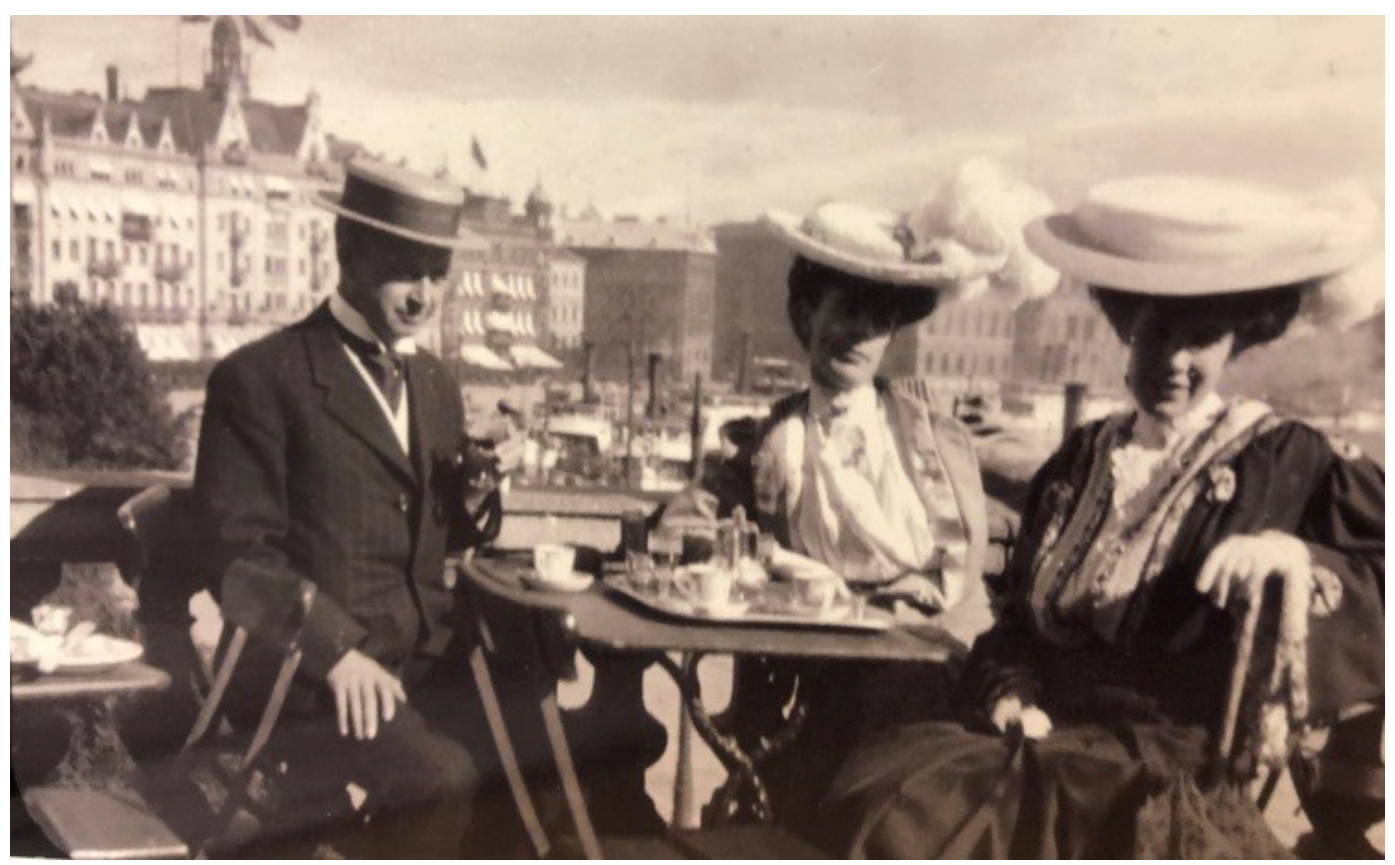

Ralph Bartlett with Sara Thorp Bull (center) and Olea Bull in Stockholm, 1906. The Grand Hotel (as it appeared before later renovations) is in the background. Courtesy of Peter Narbonne, Eliot, Maine.

The trip that began in 1911 continued on to Sweden, Finland, and, in January 1912, to Russia. This trip was a defining moment in the life of Ralph Sylvester Bartlett, Esq. Aside from that 1906 trip to Scandinavia, his most exotic travel destinations were Council Bluffs, Iowa, and a summer on Narragansett Bay.

The University of Maine at Orono holds both his one-volume travel diary for the period 1912 through 1924, amusingly titled by the author as "Manuscript Travel Diary Covering Nine Different Trips Europe and USA First Class All the Way," as well as his travel film collection, which covers the period 1925 to 1933. ${ }^{21}$ During that eight year period, his travels included the Arctic Sea, Egypt, Belgium, the Azores, Dalmatia, Estonia, Hungary, Poland, Palestine, Syria, and present-day Iraq, among many, many other destinations, that in his words were "remote regions rarely visited by tourists." I count at least forty overseas destinations in the inventories of the University of Maine film collection. In 1924, for example, he motored across North Africa, from Marrakesh to Tunis, sleeping in tents with his "faithful Arabs," and, writing to his class secretary from the latter city that "After a visit here I shall go to Sicily, but have no definite plans further than that. In all probability, I shall remain in Europe until fall." ${ }^{22}$ In 1925, he spent seven months traveling from Iraq and Turkey; in 1926, five months in the Balkans. In 1927, he was spending a weekend at the historic Rila Monastery in Bulgaria, followed by meanderings through the Baltics, Scandinavia, and Russia; in 1928, the month of September was spent in Russia, during which he writes that he "... had many interesting experiences..."; in 1929, his travels took him to the Arctic Circle, Norway and the Low Countries. His yearly extended trips almost always appear to have included stops in both Norway and Russia "combining business with pleasure," as he put it. The length of these journeys-four months long, on average - suggest that, after a diet of trust \& estates, his legal practice 


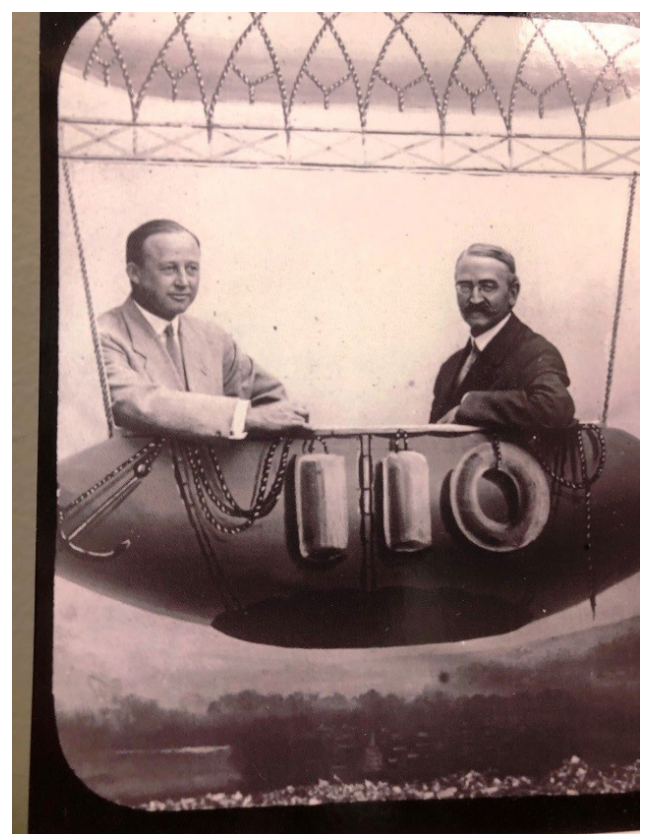

Bartlett, at left, in an undated novelty photograph. Courtesy of Peter Narbonne, Eliot, Maine. was no longer foremost in Ralph's mind.

And yet, the only destination about which he wrote extensively in his own entry for a Bartlett family history in 1957 , three years before his death at age 92 , was Russia, and in particular his first trip there in $1912 .{ }^{23}$ His account is infused with language and imagery that suggests he was captivated by what he encountered. He writes of his arrival in St. Petersburg in a blinding snowstorm, on Russia's New Year's Day; of visiting all of the historic sites, from the Cathedral of Saints Peter \& Paul, to the Hermitage. How he had dinner with an old friend Curtis Guild, Jr. (1860-1915), a former Governor of Massachusetts, who served as special Ambassador to the Russian Imperial court from 1911-13. He writes how he witnessed the blessing of the waters of the Neva, and

the appearance of the Imperial family on the balcony (to a tremendous public ovation, he adds). In his memoir, he contrasts the splendid tombs of the former emperors, with the sad fate of Nicholas II and family in Ekaterinburg. The story of the Russian imperial family was of particular interest, and found among his lantern slides are a number of images which he may have purchased from a Danish photographer, taken on the occasion of the coronation of King Haakon VII that he had attended with Sara and Olea in June of $1906 .^{24}$

Traveling on to Moscow, staying at the Metropole, he waxes poetic about his first visit to a snow-swept Kremlin in a sleigh. Passing through the Spassky Gate, he writes that

Once within the walls of the Kremlin, the experience of having a sleigh ride there amid the great conglomeration of ecclesiastical, palatial, and official buildings was mine to have and never forget. ${ }^{25}$

${ }^{23}$ Bartlett Family in America. Notes compiled by Ralph Sylvester Bartlett of the ninth generation in America, mimeographed typescript, September 1957, pp. 13-14. The copy of this compilation held by the Portsmouth Athenaeum in Portsmouth, NH, bears Ralph's armorial bookplate. In addition to traditional heraldic devices, in one quadrant his arms incorporate the Russian imperial double-headed eagle.

${ }^{24}$ The Russian royals are obviously still in mourning for Christian IX of Denmark (1818-1906), father of the Dowager Empress Maria Fedorovna (née Dagmar, 1848-1928), who had died in January. 


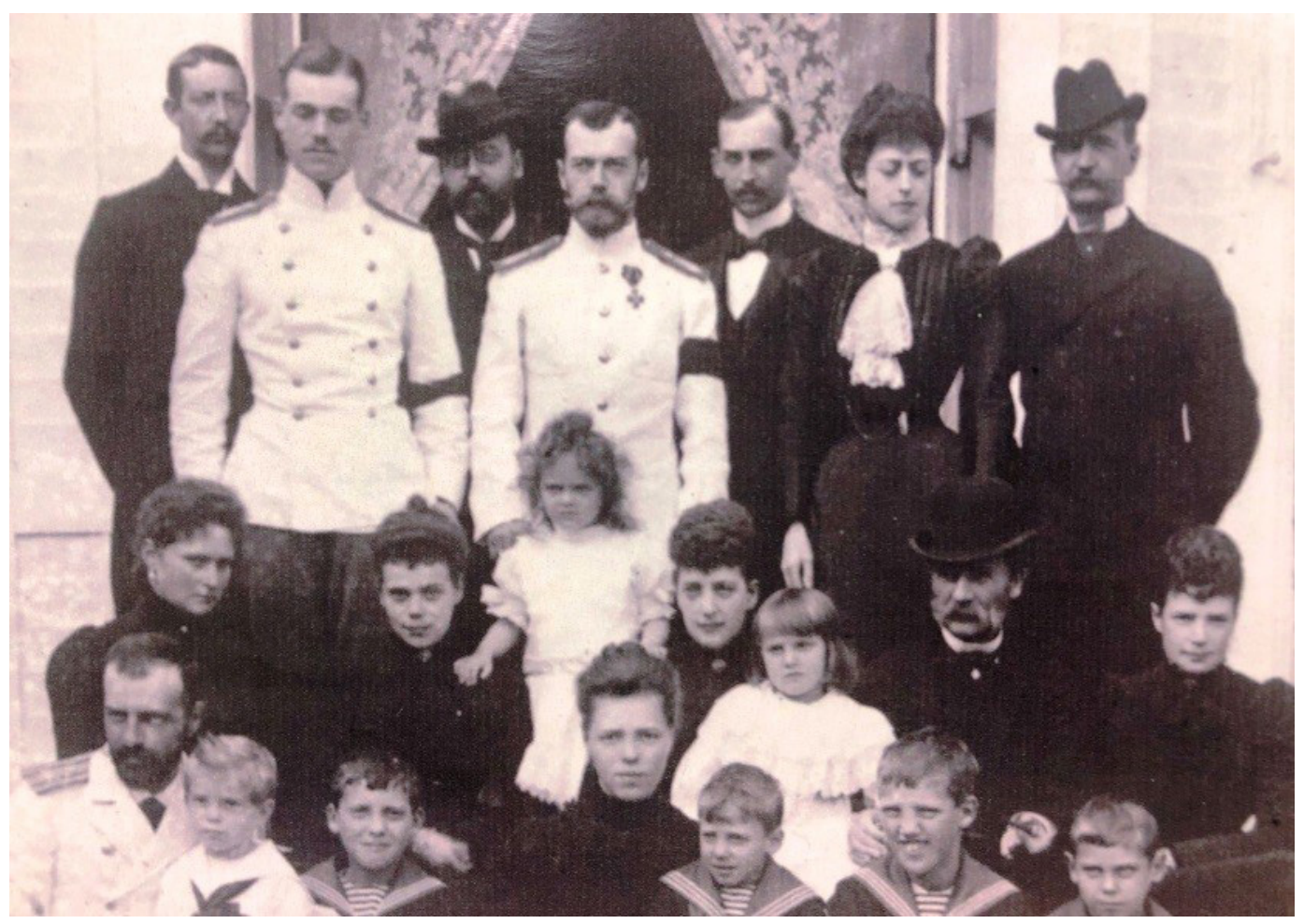

Nicholas II (center) and his wife Alexandra Fedorovna (seated at left, and Maria Fedorovna (neé Dagmar of Denmark) at lower right, among other "royals" in 1906. Courtesy of Peter Narbonne, Eliot, Maine.

He writes of visiting the Tretiakov, recalling the many works by Vasilii Vereshchagin (1842-1904) that he saw when they were exhibited in the Cyclorama Building in Boston in the 1880s (the exhibition at the Arena actually opened in October 1890). ${ }^{26}$

Ralph had always exhibited a passion for antiquities - his apartments at 139 Beacon Street, and later at $108 \mathrm{Mt}$. Vernon Street, were certainly well-stocked. He also possessed a deep-seated passion for history. ${ }^{27} \mathrm{He}$ recounts how on his first day in Hanover - the furthest he had ever been from the Great State of Maine- he was quizzed by the then-president of Dartmouth, the Reverend Samuel Colcord Bartlett (1817-98, President 1877-92), as to which common ancestor they shared. Ralph, embarrassed, admitted that he had no idea, and viewed it as his first "flunk" at Dartmouth (though, he admitted, not his last). Cut to the quick, young Ralph threw himself into the study of his past, and that of his community back in Eliot, although much of his published work on the subject appeared in print only during the last three decades of life when he was most intensively involved with the New England Historic Genealogical Society on Newbury Street in Boston, eventually giving over to them much in the way of documentation regarding Bartlett Family history. ${ }^{28}$

${ }^{26}$ For press coverage of the exhibition in Boston, see "Exhibition of Vassill Verestchagin's famous Russian war pictures," Boston Globe, September 21, 1890.

${ }^{27}$ See, for example, his The History of York County, Maine and a Rambling Narrative about the Town of Eliot and its mother-town Old Kittery with Personal Reminiscences (privately printed, 1938).

${ }^{28}$ The author wishes to thank Archivist Timothy Salls of NEHGS for his valuable 


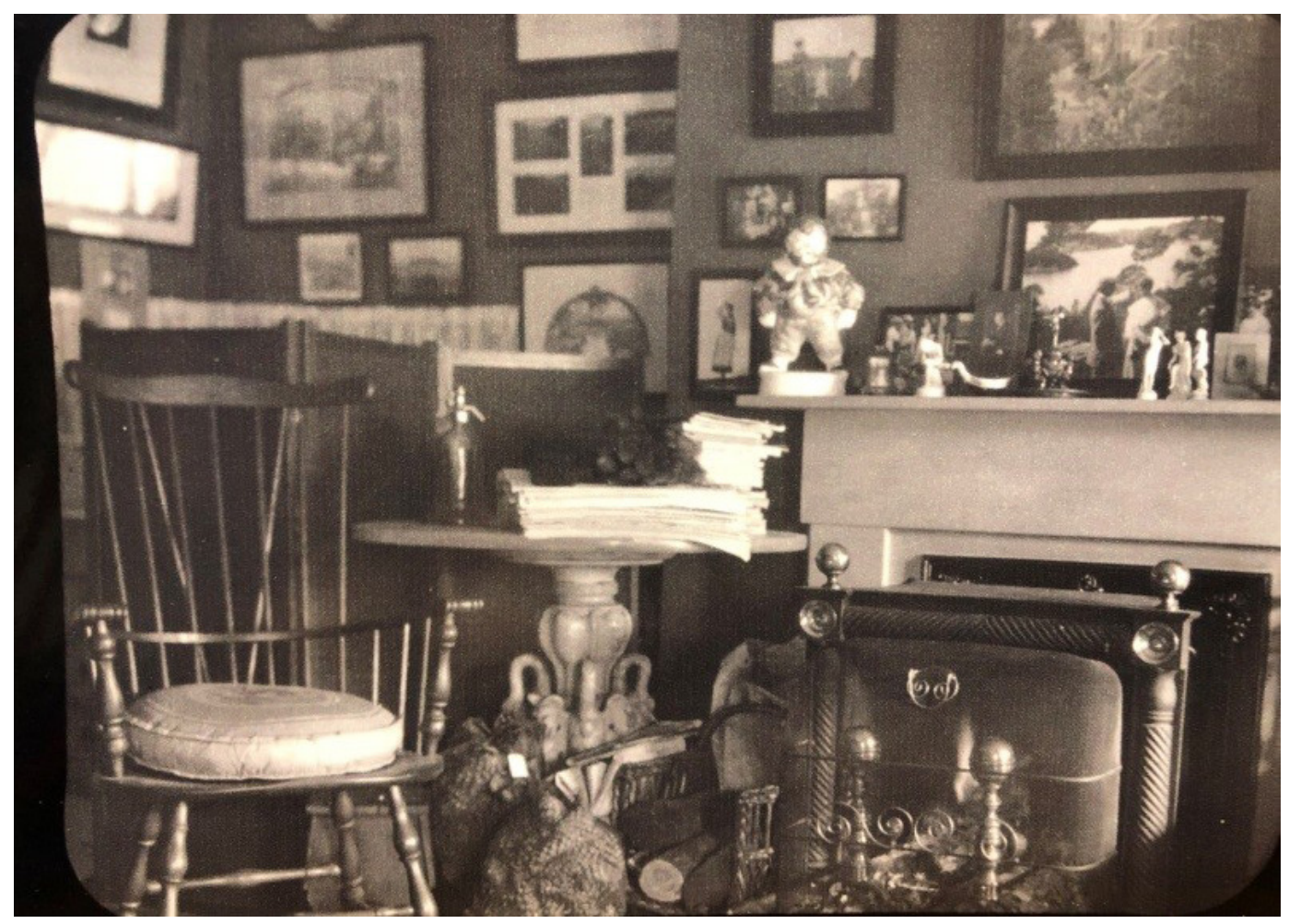

Ralph Bartlett's apartment in Boston.

In the concluding section of one of his genealogical works, he quotes Thomas Macaulay: "Any people, who are indifferent to the noble achievements of their ancestors, are not likely to achieve anything worthy to be remembered by their descendants." 29

However, it was to the selling of Russian antiques that Ralph turned his hand as a second career. Perhaps inspired by his commercially-inclined nephew C. Edward "Ned" Bartlett (1915-2004), an antique dealer in Eliot, or his cousin Alfred (1870-1926), the owner of Alfred Bartlett Books, a publisher and bookseller on Scollay Square in Boston, ${ }^{30}$ Ralph decided to establish an antiques shop. In March 1928, while still nominally a practicing attorney, he opened "Old Russia," located on the second floor of 16 Arlington Street in Boston, across the street from the Ritz-Carlton and the Public Garden. In Bartlett's own words:

It was a gallery devoted chiefly to a collection of objects formerly in the palaces, museums, and ancient monasteries of

assistance in locating their files of Dartmouth College class books donated by Bartlett.

${ }^{29}$ Bartlett Family in America, Op. cit., p. 15.

${ }^{30}$ Alfred Bartlett, Dartmouth Class of 1894, published the so-called Cornhill Booklet series, which included everything from verse to literary calendars. Evidently, the press/ shop at 69 Cornhill burned to the ground in 1912, destroying much of his stock. According to one branch family history, he also sold rare books and "first devised and popularized the American Christmas greeting card." See "Descendants of Daniel Goodwin of Eliot, Maine, Third Edition," Compiled by John Eldridge Frost (1917-92) and Beth Ann Brychta Frederick. Edited by Wilfred Collier Jr. (2017), available as a PDF, p. 70. 


\section{Imperial Russia personally gathered by me from the An- tiquariat [Antikvariat-RD] of the Soviet government. ${ }^{31}$}

Each year, from 1927 through 1933, and again in 1938, Bartlett returned to Russia to add to his stock, and tour the country. In 1933, Ralph wrote that

For the past five years, I have devoted considerable time to the development of an outside interest which took permanent form... in the opening of the shop "Old Russia"... [which] contains principally collections I have acquired from Soviet Russia during my frequent visits there. ${ }^{32}$

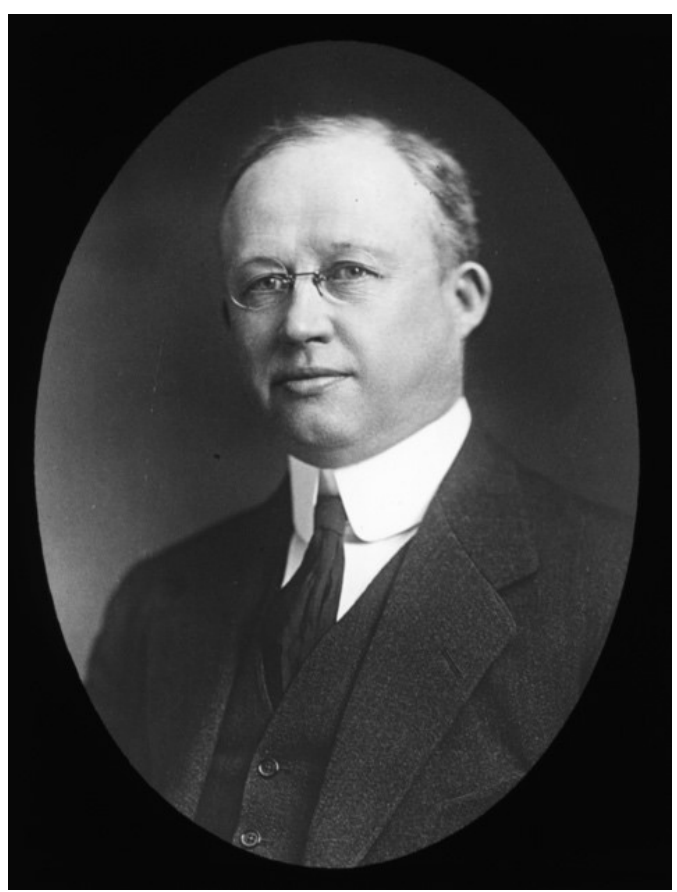

Figure 11: Bartlett in 1917. Courtesy Peter Narbonne, Eliot, Maine.

The shop was opened at a propitious time for appreciation of things Russian, and indeed, as a "bricks-and-mortar" retail establishment, it was actually a bit ahead of its time: the wildly popular itinerant commercial exhibitions of imperial provenance items at department stores in New York and the Midwest, ${ }^{33}$ organized by the Hammer Brothers Armand (1898-1990) and Victor (1901-85), were initiated only in 1933. The Hammer Galleries' physical premises (in Palm Beach and Manhattan) were established only in 1934 and 1935, respectively. ${ }^{34}$

In the fall of 1933, after formally retiring from legal practice, he was back in Russia and

...procured important additions to this collection. While abroad... I traveled rather extensively in Russia (about 5,000 miles) visiting Ukraine, the Caucasus, the Crimea, and the Black sea regions, including a motor trip over the Georgian Military Highway... ${ }^{35}$

${ }^{31}$ Bartlett Family in America, op cit., p. 12. Antikvariat was established by the Soviet government in 1921 to manage the sale (and export) of art objects, jewelry, books and furniture confiscated from private individuals, religious institutions, art museums, and the collections of the Russian imperial family. They operated both physical stores aimed at the tourist market, and handled sales abroad via dealers and auction houses.

${ }^{32}$ Dartmouth College Class of Eighty-Nine Twelfth Report, May, 1933, p. 11

${ }^{35}$ The Nineteen Thirty-Four Letters of Dartmouth '89. Thirteenth Report, January 1935, p. 30. 
In the context of travelers to Soviet Russia during the interwar period, Ralph was a bit unusual. He was not an academic like Harvard's Archibald Cary Coolidge (1866-1928), ${ }^{36}$ nor a journalist (and fellow traveler) like Anna Louise Strong (1885-1970). He was not an artist like Paul Robeson (1898-1976), or librarians like Avraham Yarmolinsky (1890-1975), and Harry Miller Lydenberg (1874-1960). ${ }^{37}$ He certainly did not possess any formal academic training in the region's history, or have any familial ties, political connections or sympathies, or Slavic language training. As a purveyor and collector of Russian antiquities, he most definitely lacked the marketing skills of his New York-based contemporaries. ${ }^{38} \mathrm{He}$ had neither the focused passion of Faberge collector India Early Minshall (18851965), ${ }^{39}$ or the impeccable timing of Marjorie Merriweather Post Davies (1887-1973), wife of the United States' second Ambassador to the Soviet Union. ${ }^{40}$ Rather, as a consequence of his perambulations throughout the world, he essentially stumbled into the Russian market, developed a personal attachment to the decorative arts of the ancien regime at a time when they could be acquired relatively cheaply from nationalized stocks in situ, and bought what he liked, indulging his second career as an gentleman antiquar-

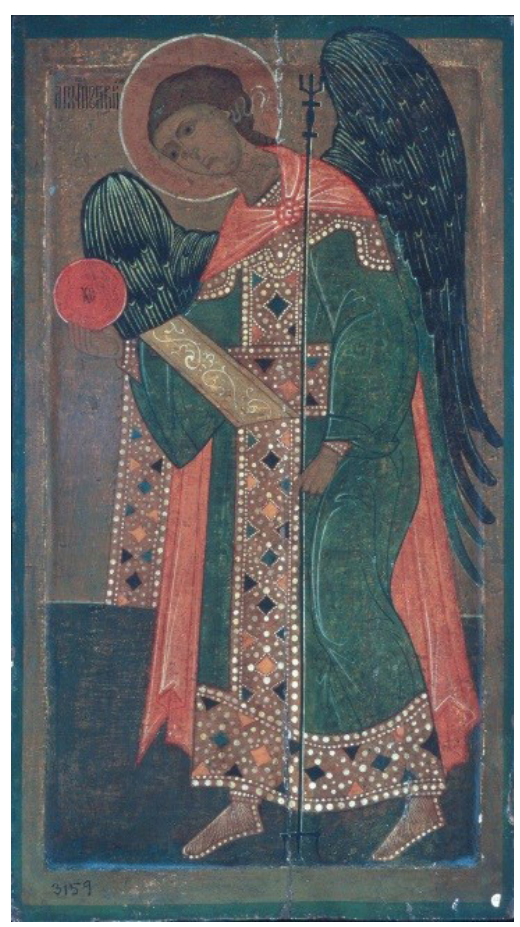

Figure 12: Unknown Russian, Archangel Gabriel, $17^{\text {th }}$ c., tempera on wood panel. Hood Museum of Art, Dartmouth: Gift of Ralph Sylvester Bartlett, Class of 1889; P.966.22.

${ }^{36}$ In addition to his service as Secretary to the American Legation to St. Petersburg (1890-91), Coolidge taught a course in "Northern European History" at Harvard, was a member of the American Relief Administration in 1921, and became a major purchaser for Harvard of nationalized book collections during the interwar period.

${ }^{37}$ On the book-buying activities in Soviet Russia by Harvard's Coolidge and, most especially by The New York Public Library's Yarmolinsky and Lydenberg, see: A Dark Mirror: Romanov and Imperial Palace Library Materials in The New York Public Library. A Checklist and Agenda for Research. With a preface by Marc Raeff and an introductory essay by Robert H. Davis, Jr. and Edward Kasinec. (New York, 2000), pp. 1-46 passim.

${ }^{38}$ For one account of how nationalized art (in this case, icons) was marketed in the United States during the 1930s, see: Wendy E. Salmond, "How America Discovered Russian Icons: The Soviet Loan Exhibition of 1930-32," in Jefferson J.A. Gatrall and Douglas Greenfield, eds. Alter Icons: The Russian Icon and Modernity (University Park, PA, 2010), passim.

${ }^{39}$ Minshall willed her Fabergé collection to the Cleveland Museum of Art. Her principal suppliers were A la Vielle Russie, and Hammer Galleries.

${ }^{40}$ Mrs. Davies, heir to the Postum Cereal, and General Foods fortune, was married to Ambassador to the Soviet Union Joseph E. Davies (1876-1958), and resided in Moscow from 1938-39. Davies himself assembled a collection of icons and paintings, a selection of which were donated to the Chazen Museum at the University of Wisconsin in 1937. 
ian in Boston.

Ralph's cousin, the noted New England historian and philanthropist Joseph William Pepperrell Frost (1923-2008) recalled to me that Ralph's customers included Alfred Gwynne Vanderbilt II's (1912-99) first wife, née Manuela Mercedes Hudson (1920-78), who returned to exchange a pair of sconces. ${ }^{41}$ In the Hood Museum archives there is also mention of a visit to the shop by a "Princess Radziwill" - quite possibly the eccentric memoirist Catherine (1858-1941). In 1938, Ralph wrote that Old Russia's “display rooms are visited by people from nearly every part of our country, and quite a good many from abroad. Its advertisements appear... in The Connoisseur, and Apollo." ${ }^{42}$ However, again according to his cousin, the late Joe Frost, the financial success of Ralph's second career was undermined by the fact that Ralph was far more interested in owning and enjoying these antiques, than he was in selling them, so his turn at business was ultimately not a commercial success. This, coupled with ominous political events in the Soviet Union and health set-backs, ultimately brought Ralph's “Old Russia” venture to a close.

The fall of 1938 marked Ralph's final visit to Russia. In contrast to his long visits in the past, he wrote that he "spent a week in Moscow and Leningrad, intending to remain longer, but finding conditions there so changed from those existing on my previous visits, I took a rather hurried leave and departed by way of Finland." ${ }^{43}$ Clearly, Bartlett sensed the atmosphere of fear, paranoia, and hostility that gripped Soviet Russia in the wake of Stalin's purges. One wishes he had provided more detail as to the particulars of his experience.

In February 1939, Ralph suffered

a short, though rather serious illness, which finally induced me to decide, in light of the grave situation abroad at that time, to free myself of the responsibility of longer continuing the existence of Old Russia, which for the past eleven years had been maintained... for my Imperial Russian Collection. ${ }^{44}$

The doors closed April 29, 1939, the day of his seventy-first birthday.

Judging by the collections at Dartmouth, many of his rarest pieces didn't sell, or, more likely, he was simply unwilling to part with them. It is hard to imagine that spectacular items now at the Hood Museum - such as a gold and silver tankard, made in Danzig for the Muscovite court in 1664, or the silver gilt tea service of Catherine the Great - couldn't find buyers. Joe Frost remembered helping Ralph pack and transfer barrels of other Russian antiquities from the shop, and putting them in

${ }^{41}$ Series of interviews in September-December of 2007 at Joe's Eliot, Maine home, conducted by Joan Waldron, and the present author.

${ }^{42}$ The Nineteen Thirty-Eight Letters of Dartmouth '89. Fourteenth Report. June, 1938, p. 15. Tragically, Ralph's actual customer lists, and correspondence files with Antikvariat, the Russian agency with whom he dealt, were destroyed in Joe Frost's flooded basement some years ago.

${ }^{43}$ Ibid., p. 15.

${ }^{44}$ The Nineteen Forty Letters of Dartmouth '89. Fifteenth Report. June 1940, p. 26. 


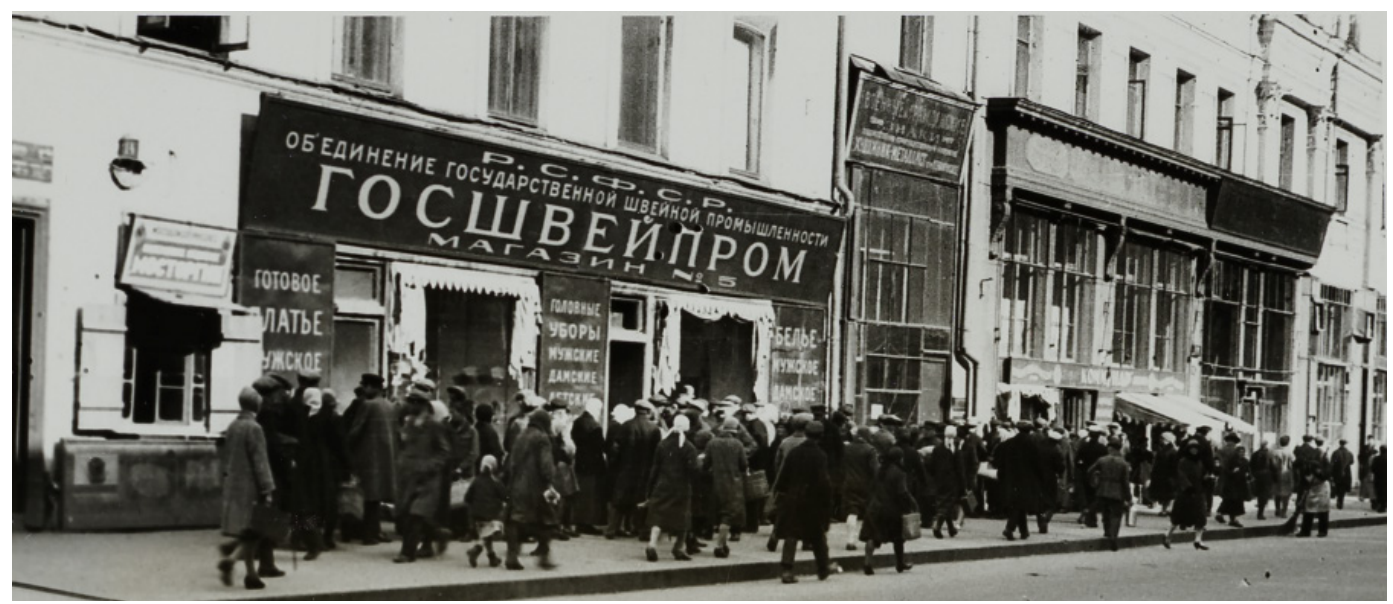

Figure 13: Ralph Sylvester Bartlett. A Line for Clothing, Moscow, 1930, gelatin silver print. Hood Museum of Art, Dartmouth: Gift of Ralph Sylvester Bartlett, Class of 1889; PH.2004.24.101.

temporary storage in the Shapleigh family barn in Lebanon, Maine, and gradually brought back to decorate his apartment on Mt. Vernon Street. Some of the prize pieces were loaned to various New England museums and historic houses. The Fogg Museum at Harvard, for example, took for exhibition some of Ralph's icons; the Museum of Fine Arts, some of the metal objects; the Harrison Gray Otis House at 141 Cambridge Street in Boston, furniture, and so forth. According to Joe Frost, still other choice pieces he gave to his former ward, Sylvea Bull Curtis, including a pair of wine coolers from the Tsarskoe Selo service, made in St. Petersburg by Zacharias Deichman the Elder (fl. 1731-76). She donated these to New York's Metropolitan Museum of Art in $1981 .{ }^{45}$

Bartlett's pride in his alma mater was evident throughout his long life. As a loyal son of Dartmouth, he early on became active in the Dartmouth Club of Boston, and throughout the thirties, forties, and fifties he was regularly donating "Dartmouthiana" to the College. Everything from early $19^{\text {th }}$ century diplomas, to an album of signatures of prominent graduates in 1896; from the recovery of a long-ago pilfered bust of Daniel Webster from the College Library when it was located in Reed Hall, to photos of an 1887 Vermont train wreck that killed a classmate. In 1958, he wrote to the archivist of the College that he was transferring all documentation and correspondence he had pertaining to members of the Class of 1889 , as he was then in his ninetieth year, and its only surviving member. ${ }^{46}$

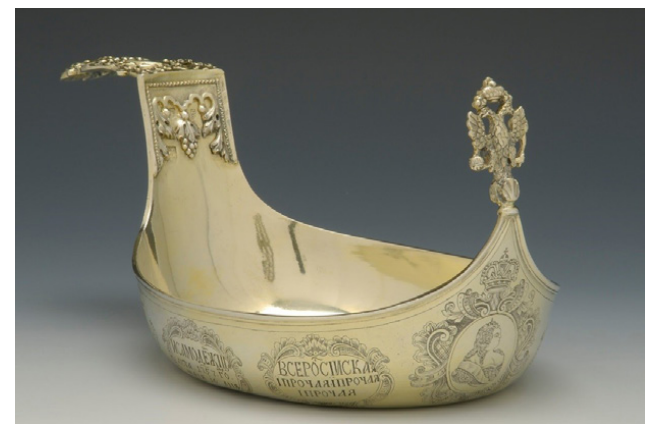

Unknown Russian, Gilt Kovsh Dish, 1757, gold and silver. Hood Museum of Art, Dartmouth: Gift of Ralph Sylvester Bartlett, Class of $1889 ; 159.2 .19450$.

${ }^{45}$ An image of one of the wine coolers may be found on the Metropolitan Museum of Art's website: https://www.metmuseum.org/art/collection/search/206898

${ }^{46}$ Letter from Bartlett addressed to the Archivist of Dartmouth College, September 11, 1958. Dartmouth College Library. Rauner Special Collections. Bartlett File. 


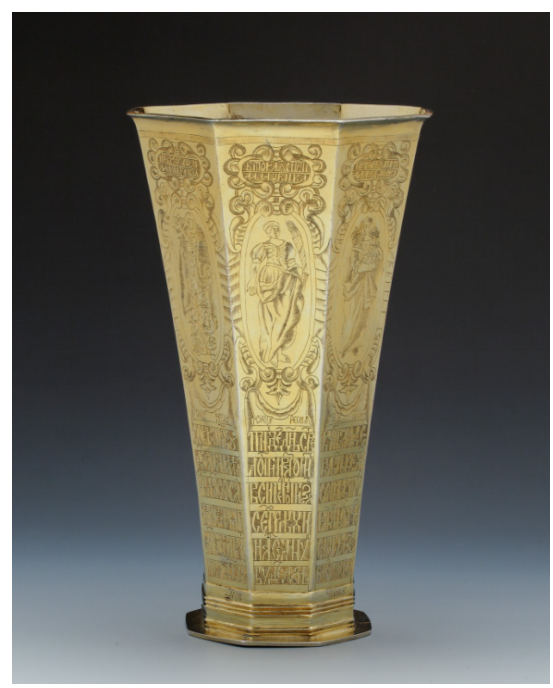

Unknown Russian, Beaker Depicting Eight Sybils, 1682, silver gilt. Hood Museum of Art, Dartmouth: Gift of Ralph Sylvester Bartlett, Class of 1889; 159.2.19461.

material to be deposited in a Russian section of the Dartmouth Archives." 50 The

${ }^{47}$ Von Mohrenschildt ((1902-2002) immigrated to the US in the 1920s, received a doctorate from Columbia, and went on to become a professor at Dartmouth and later Stanford. It is not clear why copies of Goodrich's correspondence on Dartmouth library matters are part of von Mohrenshildt's papers.

${ }^{48}$ Dimitri Von Mohrenschildt Papers, Box 1, Hoover Institution Archives. With thanks to Edward Kasinec, Visiting Fellow at the Hoover, for reproducing the letters during a recent visit to Palo Alto.

49 "White Russians Turn to Dartmouth as Future 'Capital' for Tsarist Records," Christian Science Monitor, December 7, 1934, p. 15. The article was retitled as "White Russians Find College As New Capital," and largely reproduced verbatim in The China Press of January 6, 1935, p. 9.

In his letter, Bartlett references an article "Dartmouth to House Old Russian Archives," in The New York Times of December 16, 1934; however, I have not been able to locate it.

50 "White Russians Turn to Dartmouth...," Op. cit., p. 15. Thanks to materials located in the archives by Eric Esau of Dartmouth's Rauner Special Collections Library, we have a bit more detail on the biography of Chernikoff. His application for citizenship indicates that he was born in Voronezh, but his original "home" address is listed at Ekaterinoslav in a 1928 survey of Tuck alumni. After serving for two years (1918-19) in the infantry, and later an an armored division with the White Armies of General Deniken, and Baron Wrangel, he lived in Belgrade, where he studied law prior to leaving for the U.S. in November 1923 via Bremerhavn. In his 1923 application for citizenship, his occupation is given as "Supt. of Division Foreign Pub." (The National Archives at Philadelphia; Philadelphia, Pennsylvania; NAI Title: Declarations of Intention for Citizenship, 1/19/1842-10/29/1959; NAI Number: 4713410; Record Group Title: Records of District Courts of the United States, 1685-2009; Record Group Number: 21.

Following graduation from Tuck he worked as a bookkeeper for Remington Rand 
committee included Grand Duchess Marie (1890-1958), Princess Xenia (190365) and her sister Nina (1901-74), Nina's husband Prince Paul Chavchavadze (1899-1971), Prince George Chavchavadze (1904-52) a "General Imnadze," and Professor Homer D. Lindgren (d. 1942) of NYU. ${ }^{51}$ Bartlett opined:

That our college is to undertake the important work of collecting and preserving historical documents relating to Imperial Russia, now so widely scattered throughout the world, is most pleasing. ${ }^{52}$

He mentions that:

In my collection are pieces belonging to former Tsars as far back as Peter the Great, some of which I may wish to donate, if found to be appropriate, to Dartmouth's "White Russian Archives." 53

In his reply, Goodrich thanks Bartlett for his offer ("You may be very sure that if at any time you should feel like presenting anything to our collection we shall be most happy to receive it"),${ }^{54}$ and then explains that:

We are acting simply as the depository for this material, and the collecting of it is being done by Mr. Chernikoff and those whom he is able to interest in the matter. So far it is no more than a project, but Mr. Chernikoff is very energetic and confident and we have hopes that it will in time become something worth while. ${ }^{55}$

in their "Foreign Publicity Department." He filled out his following year on October 25, 1929, just days before the Crash. The following August, when he filled out the following year's Tuck alumni survey, he was working in the export department of Cotex Corporation, a manufacturer of leather and rubberized cloth, corroborating the 1930 U.S. Census, where his occupation is listed as "leather salesman" (Year: 1930; Census Place: Manhattan, New York, New York; Page: 14B; Enumeration District: 0244; FHL microfilm: 2341293). By 1931, he was unemployed, and it is only in the 1933 survey that he indicates his position as Head of the "Russian Information Center in the U.S.A." where the nature of his business is provide "authentic facts on Russian matters" disseminated via bi-monthly bulletin.

${ }^{51}$ Lindgren was a professor of public speaking in NYU's School of Commerce, Accounts \& Finance.

${ }^{52}$ Bartlett to Goodrich, January 18, 1935, [p. 1]. Dimitri Von Mohrenschildt Papers, Box 1, Hoover Institution Archives. The typed letter is on "Old Russia" stationery.

${ }^{53}$ Ibid., [p. 1].

${ }^{54}$ Nathaniel L. Goodrich to Bartlett. January 21, 1935. Dimitri Von Mohrenschildt Papers, Box 1, Hoover Institution Archives.

${ }^{55}$ Ibid., Goodrich to Bartlett, January 21, 1935. 
He also put Bartlett directly in contact with Chernikoff, who replied to Ralph's February 15 letter that he had been "very sick" for the past two months, and stated that:

I have no doubt that any gifts you may care to make would be accepted with pleasure both by the Officials of the Baker Memorial Library and by the members of the General Committee. ${ }^{56}$

The White Russian Archives proposal fell apart following Chernikoff's aforementioned illness, and subsequent death from liver cancer on June 5, 1935. ${ }^{57}$ One of the first persons with whom his widow made contact was Tuck Dean William R. Gray (1880-1937). wrote in reply that:

Vanya's [i.e., Chernikoff's] plan for developing the Russian archives at the College was typical of his desire to make a lasting contribution to Dartmouth and to the Russian cause. It is most gratifying, therefore, to have your assurance that you and Vanya's friends have undertaken to carry on with this significant project. ${ }^{58}$

Gray was a regular correspondent with Chernikoff since shortly after the latter's graduation. On at least one occasion, Dartmouth paid Chernikoff a \$25 honorarium for meeting with Amos Tuck students in January 1933. ${ }^{59}$

What, if any correspondence took place among the illustrious committee members following young Chernikoff's passing, or between Bartlett and this

${ }^{56}$ [Ivan Chernikoff] to Bartlett, February 21, 1935. Dimitri Von Mohrenschildt Papers, Box 1, Hoover Institution Archives. The letter bears no signature, but the address - 503 West $138^{\text {th }}$ Street-is that of Chernikoff as provided by Goodrich.

57 The front page of the June 8, 1935 issue of the New York-based Russian émigré newspaper Novoe russkoe slovo includes a brief notice of his death (in "Whitestone, Long Island"). At the time, his residence was in the Queens neighborhood of Beechurst. $\mathrm{He}$ is buried in Flushing Cemetery in Queens

${ }^{58}$ [W.R. Gray] to Mrs. Maria Ottor Chernikoff. June 18, 1935. Dartmouth College Library. Rauner Special Collections. DA5 Box 2425 Chernikoff File.

59 On December 7, 1934, Chernikoff wrote to Gray with what was essentially a proposal to teach "first Foreign Trade, and then everything pertaining to Russia." Noting that "My spiritual life has gone through difficult times... I don't think I want to go back into business, if I can help it. I prefer teaching as a profession."(I. Chernikoff to William R. Gray. December 7, 1934. Dartmouth College Library. Rauner Special Collections. DA5 Box 2425 Chernikoff File). He reminds Gray that he had sent outlines from his lectures, "from which I hope you could see the trend of my development in recent years."

Gray's response of December 10, 1934, applauds Chernikoff's decision to focus on a teaching career, yet points to the need for further graduate study, and the paucity of positions in the Depression Era. He also comments that

Praiseworthy and sincere as your interests in Russian affairs may be, I have been unable to see how or where they would lead you into a realistic and substantial working purpose... (William R. Gray to Ivan I. Chernikoff. December 10, 1934. Dartmouth College Library. Rauner Special Collections. DA5 Box 2425 Chernikoff File). 
committee or Goodrich, remains to be investigated.

Another correspondent with Dartmouth at this time-again, prompted by Chernikoff's efforts - was Jacques Markovich Lissovoy (Iakov Markovich Lissovoi, 1882-1965), a former Imperial, and later White Army officer, who left Russia in 1920 via Constantinople, then Yugoslavia, before landing in Chicago in 1923, and becoming a U.S. citizen in 1928. Lissovoy wrote directly to Dartmouth's then-president, Ernest M. Hopkins (1877-1964):

I am writing you in the hope that I may be given the opportunity to place my extensive collection of historical material at your disposal. This collection is known as the "Museum of Contemporary Events in Russia" and ranking third in the World, is perhaps the finest collection of historical data, of its kind, in the United States. ${ }^{60}$

The brief inventory he provides with the letter, arranged into twenty-one categories of material (Books, "Very rare newspapers", Handbills, Cartoons, etc.) gives a ballpark figure in excess of 20,000 items. Lissovoy concludes by stating that:

In summary, my idea is to make Dartmouth's Russian Collection the first in the United States and the best known throughout the World., to create a Russian "Mekka" [sic] for all historical pilgrims... ${ }^{61}$

As Hopkins was then abroad, on February 18, 1935 his Executive Assistant Albert I. Dickerson (1908-72) responded to Lissovoy, explaining that under the circumstances (presumably of the Depression) that there was no present prospect of adding staff, nor did Dartmouth at that moment have library and archival staff competent to process his collection. Dickerson suggests that, upon administrative reflection, the announcement regarding the creation of the White Russian Archives at Dartmouth may have been a bit premature:

The question was raised at the time... the proposal was made whether there would be any possibility of putting anyone to work upon the archives, since there is no one in the College organization with the background or knowledge of the Russian language which would be necessary, It was very promptly

${ }^{60}$ Jacques M. Lissovoy to Ernest Martin Hopkins, February 10, 1935. Dimitri Von Mohrenschildt Papers, Box 1, Hoover Institution Archives. According to Lissovoy, the archive was

...collected for the most part in Russia during the World War, the Revolution, and the Anti-Bolshevistic Movements, but much data has been added since that time as the result of careful research and advantageous contact in various other nations.

${ }^{61}$ Jacques M. Lissovoy to Albert I. Dickerson, February 27, 1935. Dimitri Von Mohrenschildt Papers, Box 1, Hoover Institution Archives. 
found, however, that there was no possibility of doing this and the archives were established definitely on the basis of their being for the present time no more than a safe and systematic depository for valuable papers which should be preserved for the use of future historians. ${ }^{62}$

Dickerson, in a follow-up letter responding to Lissovoy's correspondence of February 27,1935 , in which the latter spelled out what he could do for Dartmouth as, essentially, an employee, was more blunt:

...circumstances are such that... it would be a mere waste of effort to continue discussion of the possibilities of developing our White Russian archives in the full and active way which would be possible could we provide for your affiliation with the work. At a time when it is necessary to restrict as far as possible the costs of its direct instructional program, the Trustees feel it is unwise to consider any expenses for research projects that have direct connection with instruction. ${ }^{63}$

Dickerson closes with a statement that appears to have been the final nail in the coffin of the Chernikoff-Lissovoy White Russian archives at Dartmouth:

As a matter of fact, we [i.e., the Dartmouth Trustees and academic administration] have felt in connection with the White Russian archives that this was not properly a project for such a college as Dartmouth, primarily devoted to undergraduate instruction, but rather for a university in a metropolitan city where a great deal of research is being done. ${ }^{64}$

On July 20-21, 1940, in his adopted home town, Lissovoy offered up a substantial exhibit of over 12,000 (!) items on the theme of "Wars of the World" at the Army and Navy Club on South Michigan Avenue. The exhibit covered from the Crimean War to the present, and by all evidence filled every public space of the clubhouse, and was characterized as representing "... only one chapter of Col. Lissovoy's collections." 65

${ }^{62}$ Albert I. Dickerson to Professor Jacques M. Lissovoy, February 18, 1935. Dimitri Von Mohrenschildt Papers, Box 1, Hoover Institution Archives. Lissovoy's title acknowledges that he taught at Emerson Junior College in Chicago.

${ }^{63}$ Albert I. Dickerson to Professor Jacques M. Lissovoy, March 1, 1935. Dimitri Von Mohrenschildt Papers, Box 1, Hoover Institution Archives.

${ }^{64}$ Ibid., Dickerson to Lissovoy, March 1, 1935.

${ }^{65}$ A copy of a multipage pamphlet, including a brief biography of Lissovoy, entitled The National Home Defense Guard of Illinois presents The "Wars of the World" has been digitized by the FDR Library in Hyde Park, New York, and may be downloaded as a PDF. While in emigration in Paris, Lissovoy published the first (of eventually three) volumes of 
Ultimately (and surprisingly, given his White Russian background), in 1942 Lissovoy approached the State Public Historical Library of Russia (GPIB) in Moscow, offering the donation of his archives, which was promptly accepted, and the collection transferred to the GPIB in the late 1940s. After receipt, official Soviet correspondence with Lissovoy ended, and, as reported by the chief librarian of GPIB's Russian Abroad collections: "...promises concerning "processing" and "storage as a special collection" remained only promises." ${ }^{66}$ Regretfully, his collection was soon divided among other archival collections, and the volumes, films, art work, etc. collected by Lissovoy were integrated into either spekts khrany or general stack collections.

The discovery of the Chernikoff and Lissovoy correspondence revealing that Dartmouth was once considering - however briefly_-becoming a major repository for the archival legacy of the White Russian emigration is quite remarkable. For decades, it was assumed that, aside from the establishment of the Hoover archives following World War I, the formation of the Bakhmeteff Archive ${ }^{67}$ at Columbia in April 1951 represented the second major attempt at an in-gathering of the accumulated legacy of the Russian "first wave" emigration. ${ }^{68}$ In fact, in an undated letter from Chernikoff to Goodrich located in the Hoover, he reports that Paul Chavchavadze "is at present negotiating with the Honorable Boris Bakhmeteff with the hope of getting his official files..." ${ }^{69}$ Chavchavadze was unsuccessful, as

Belyi arkhiv. The 1926 volume has been digitized and is available at the Internet Archive. See: https://archive.org/details/bielyiarkhivseri008800/page/344/mode/2up

${ }_{66}$ Andrei Sergeevich Kruchin. "Kollektsiia IA.M. Lisovogo: put; chastnogo sobraniia." (article from Biblioteka lichnaia-biblioteka obshchestvennaia: traditsii otechestvennogo knigosobiratel'stva: materialy nauchnoi konferentsii, 7-8 oktiabria 1998 goda (M.:GPIB, 2001). See: https://www.shpl.ru/about_library/history_library/collections/ kollekciya yamlisovogo put chastnogo_sobraniya/

${ }^{67}$ On the history of the Bakhmeteff Archive, see the following contributions to the 2003 compilation edited by Tanya Chebotarev and Jared S. Ingersoll: "Russian and East European Books and Manuscripts in the United States: Proceedings of a Conference in Honor of the Fiftieth Anniversary of the Bakhmeteff Archive of Russian and East European Culture," a special issue of Slavic \& East European Information Resources, 4(4) 2003: Marc Raeff, "Introduction," pp. 1-3; Oleg Budnitskii, "Boris Bakhmeteff's Intellectual Legacy in American and Russian Collections," pp. 5-13; and Jared Ingersoll, "Columbia University Libraries' Slavic and East European Collections: A Preliminary History at 100 Years," pp. 77-88.

${ }^{68}$ Writing in his 1940 Annual Report of the Slavonic Division of the NYPL, shortly after the fall of Paris, Chief Avrahm Yarmolinsky reported on a systematic effort on the part of the Library "To systematize and enlarge the work of collecting fugitive literature and unpublished records of the Russian Dispersion, as well as to secure any manuscripts relating to recent Russian history which may be in private hands."(Typescript, NYPL Archives). While Yarmolinsky was successful in securing the donations of Michael Riabouchinsky archives, and the Miriam Shoner Zunser papers, further efforts on behalf of the "Russian Historical Archives" were largely eclipsed by the establishment of the Bakhmeteff. On this effort, see: Robert H. Davis, Jr. "The New York Public Library's Émigré Readership and Collections: Past, Present, and Future," in Chebotarev and Ingersoll, eds., Ibid., p. 67.

${ }^{69}$ Chernikoff to Goodrich. Undated, but presumably late February or March of 1935, 
Bakhmeteff's papers became one of the foundation collections of the Archive of Russian History at Columbia, which was later renamed the Bakhmeteff Archive.

After the short-lived flurry connected with the White Russian Archives, it would be another sixteen years before the disposition of Ralph's collection would resurface. Ultimately, the trigger for making Dartmouth the sole beneficiary of his Russian collection appears to have been the publicity surrounding the establishment of an inter-disciplinary major and Department of Russian Civilization in the spring of 1951 , supported by a $\$ 50,000$ grant (almost $\$ 500,000$ in 2020 dollars) from the Carnegie Corporation. ${ }^{70}$ Dartmouth's President John Sloan Dickey (1907-91) wrote that:

Knowledge of the Soviet Union is an essential part of the educational experience of American college graduates. As citizens, they must be prepared to make judgments and provide leadership on crucial issues involving the Russian people, with whose culture and political behavior they are relatively unfamiliar. ${ }^{71}$

Bartlett himself had expressed such a sentiment as early as 1934, when he wrote

During my annual visits to the Soviet Union, since 1927, intensely interesting and important changes have taken place, and I know of no country where there have been and still are so many opportunities for observing and studying at first hand economic, social and other problems of government. ${ }^{72}$

In April of 1951, Bartlett wrote to Harold Goddard Rugg (1883-1957) of the College Library, regarding a proposed donation of Russian textiles. He reported that

....when it was possible to acquire from the Soviet government interesting objects that were in the palaces, museums and monasteries in tsarist times, I gathered for my Russian collection among other things an imperial cloth of gold - reputed to have been a tsar's robe, some old and beautiful priest's robes, the wedding dress intended for Grand Duchess Olga, beautiful old altar-cloths, embroidered pieces from ancient mon-

as he mentions (and includes a copy of) his reply to Bartlett. Dimitri Von Mohrenschildt Papers, Box 1, Hoover Institution Archives, [p. 1]. He goes on to note that "The Grand Duchess Marie is actively corresponding with Europe" in their efforts to secure archival collections [p. 2].

Bakhmeteff (1880-1951) was the Russian Provisional Government's only Ambassador to the United States, and later became professor of civil engineering at Columbia.

${ }^{70}$ See, for example Fred M. Hechinger, "New Russian Studies: Dartmouth to Offer Broad Program As Vital Need in World of Today," New York Herald Tribune, April 15, 1951, p. A6.

71 "Dartmouth Sets Up Program on Russia," New York Times, April 15, 1951, p. 69.

${ }^{72}$ The Nineteen Thirty-Four Letters of Dartmouth '89. Thirteenth Report. January 1935, p. 30. 
asteries, etc. etc. ${ }^{73}$

Later, in August, he wrote to Richard Morin (1902-88), Librarian of the Dartmouth College Library, of his willingness to donate an oil painting of Ivan IV, acquired in Moscow in 1928, and all issues of the journal Russia (1944-51), and closes by saying that "A little later, when my Russian collection is reassembled in better order, I will give further consideration to a possible loan from it to Dartmouth." 74

$* * *$

So, the seed was planted, and in October 1960, less than a month after Ralph's death, Alfred F. Whiting (1912-78) of the college museum wrote the first description of the Ralph Bartlett Collection, which he aptly described as

one of the ranking Russian collections in the country exceeding in quality and quantity that of Harvard and many other institutions in this country... The value of the collection to Dartmouth, particularly in view of the expanding interest in Russian language and history, is very great. ${ }^{75}$

Indeed it was, and is, and those of us in the field of Russian studies owe a great debt to Ralph for assembling it, and to Dartmouth College and its museum curators and librarians for preserving it, and making it accessible. Perhaps even more that its objets, the significance of the materials given by Bartlett is as a reflection of the monumental upheavals of the last century: the collapse of three centuries of Romanov rule and of the elite culture that it engendered; the desperate and rapacious efforts of the Soviet regime to both extirpate the remnants of the ancient regime, while handsomely profiting from it; the devastating impact of the Great Depression on American society and institutions, including deferment of noble academic aspirations that would impact America's ability to understand hostile regimes; and finally of the ultimate success of post-war commitment to remedy the "knowledge gap" via a combination of private foundation and government support to higher education. As was amply demonstrated by the diversity of topics of the 2008 Dartmouth symposium, ${ }^{76}$ these events fostered a decades-long

${ }^{73}$ Ralph Bartlett to Harold G. Rugg, April 3, 1951. Hood Museum.

${ }^{74}$ Ralph Bartlett to Richard W. Morin, August 27, 1951. Hood Museum. In a reply, Morin wrote that the painting "will be hung in the new quarters of the Department of Russian Civilization of which Professor Von Morenschildt is the Chairman." Morin to Bartlett, September 5, 1951.

${ }^{75}$ Internal memorandum, "Ralph Bartlett Collection," dated October 5, 1960, from Whiting to Paul Young in the Dartmouth College Alumni Records Office. Whiting publicly announced the acquisition as "The Ralph Bartlett Collection of Russian Treasure," Dartmouth College Library Bulletin, IV(1/2): 29 (June 1961).

${ }^{76}$ Speakers at the Dartmouth Symposium included (arranged by affiliation): Mark Schaffer (A La Vielle Russie); Stanley Rabinowitz (Amherst); Wendy Salmond (Chapman); 
political, economic, and culture dialogue between Soviet Russia and the United States. Finally, we have in the person of Ralph Sylvester Bartlett a not-unfamiliar American "type": an individual who, though not a profound specialist, had the opportunity, the interest, and the steady goodwill to further the education of future generations, at an institution he loved.

\begin{abstract}
About the Author
Robert H. Davis, Jr., is Librarian for the Russian, Eurasian and East European Collections at both Columbia, and Cornell Universities. He is the former Assistant Chief of the Slavic \& Baltic Division of The New York Public Library.

He holds undergraduate and graduate degrees from Columbia, a certificate in Russian Studies from the Harriman Institute, and the MLIS degree from the City University of New York, where he was elected to Beta Phi Mu. He has authored five books, and many articles, reviews, and communications. He has also authored, coauthored, and/or managed ten preservation and access grants funded by various federal and private entities, including the National Endowment for the Humanities and the Department of Education.
\end{abstract}

Tanya Chebotarev (Columbia); Eric Esau, Lev Loseff, Barry Scherr, T. Barton Thurber, and Christianne Wohlforth (all Dartmouth); Nicholas Lupinin (Franklin Pierce); Brad Schaffner (Harvard); Anne Odom, Kristen Regina, and Scott Ruby (all of the Hillwood Museum); Vladimir von Tsurikov (Holy Trinity); Anatol Shmelev (Hoover); independent scholars Marilyn Swezey and Geza Von Habsburg; Norman Saul (Kansas); Harold Leich (Library of Congress, and Dartmouth alumnus); Viktoria Paranuk (Metropolitan Museum, New York); Emmie Donadio and Thomas Beyer (both Middlebury); Marilyn Solvay (Norwich); Vera Shevzov (Smith); Ulla Tillander-Godenhielm (Tillander Jewelers); Cathy Frierson (UNH); and Denise Youngblood (Vermont). 